\title{
Two new species of lithobiid centipedes (Chilopoda: Lithobiomorpha) from the northern Caucasus, Russia
}

\author{
Ава новых вида многоножкек-костянок (Chilopoda: \\ Lithobiomorpha) с Северного Кавказа, Россия
}

\author{
R.V. Zuev \\ P.B. 3yeв \\ North Caucasian Federal University, Pushkina Str. 1, Stavropol 355009 Russia \\ Северокавказский федеральный университет, ул. Пушкина 1, г. Ставрополь, 355009 Россия. E-mail: romus00@yandex.ru
}

KEY WORDS: Russia, Caucasus, Lithobiomorpha, new species, taxonomy.

КЛЮЧЕВЫЕ СЛОВА: Россия, Кавказ, Lithobiomorpha, новый вид, систематика.

\begin{abstract}
Two new species of lithobiid centipedes are described: Lithobius (Lithobius) dissimilis sp.n., from the Stavropol Territory, and L. (Monotarsobius) evsyukovi sp.n., from the Republic of North Ossetia-Alania. The former new species seems to be especially similar to L. integrior (Chamberlin, 1952) and L. ispartensis Zapparoli, 1999, both from Turkey, while L. evsyukovi sp.n. belongs to the L. ferganensis group and seems to be the nearest to L. sseliwanoffi Garbowski, 1897.
\end{abstract}

РЕЗЮМЕ. Описываются два новых вида костянок: Lithobius (Lithobius) dissimilis sp.n. из Ставропольского края и L. (Monotarsobius) evsyukovi sp.n. из Республики Северная Осетия-Алания. Первый вид, кажется, особенно близок к известным из Турции $L$. integrior (Chamberlin, 1952) и L. ispartensis Zapparoli, 1999, a L. evsyukovi sp.n. входит в группу L. ferganensis и наиболее сходен с L. sseliwanoffi Garbowski, 1897.

\section{Introduction}

Research on the Caucasian Lithobiomorpha began in the second half of XIX century. Most of the papers concerned were fragmentary in character and mainly contained descriptions of new species [Sseliwanoff, 1881; Lignau, 1903; Attems, 1907; Muralewicz, 1907, 1926; Folkmanova, 1958; Zalesskaja, 1973]. Two monographic reviews were specially devoted to the taxonomy of Caucasian lithobiomorphs [Muralewicz, 1929; Zalesskaja, 1978]. According to Zalesskaja [1978], the Caucasus supports about 50 species of lithobiid centipedes, including eight in Lithobius (Monotarsobius) Verhoeff, 1905.

Two new species of lithobiid centipedes are described here. One of them comes the closest to the Turkish $L$. (L.) interior (Chamberlin, 1952) and L. (L.) ispartensis Zapparoli, 1999, clearly differing from other Lithobius s.str. species known from the Caucasus. The other be- longs to Lithobius, subgenus Monotarsobius, and is included in the L. ferganensis group, all of the constituent species of which show very similar secondary sexual characters of the male and are widespread in Eastern Europe, the Caucasus and Central Asia [Zalesskaja, 1978; Farzalieva, Zalesskaja, 2002; Farzalieva, 2006].

\section{Material and methods}

The material underlying this paper was collected by me in 2014-2015 around the city of Stavropol and by A.P. Evsyukov in 2010 in the Republic of North Ossetia-Alania (Map 1). Type specimens are deposited in the Zoological Museum of the Moscow State University, Russia. Terminology for external anatomy follows Bonato et al. [2010]. The descriptions of the coloration are based on specimens kept in $70 \%$ alcohol after 2 and 6 years since their collection, respectively. Body length was measured from the anterior margin of the cephalic plate to the posterior end of the postpedal tergite. In some specimens, dissected female gonopods were mounted on temporary slides (glycerol).

The following abbreviations are used in the text and tables: $\mathrm{a}-$ anterior, $\mathrm{C}-$ coxa, $\mathrm{F}-$ femur, $\mathrm{m}-$ median, $\mathrm{P}$ - prefemur, $\mathrm{p}$ - posterior, S, SS - sternite, sternites, sad. — subadultus, T, TT — tergite, tergites, $\mathrm{t}$ - tibia, $\mathrm{Tr}$ - trochanter.

Taxonomic part

ORDER LITHOBIOMORPHA

Family LITHOBIIDAE

Lithobius (Lithobius) dissimilis sp.n. Figs 1-15.

DIAGNOSIS: A medium-sized Lithobius (13-16 $\mathrm{mm}$ long), antennae ca $54 \%$ the length of the body, 


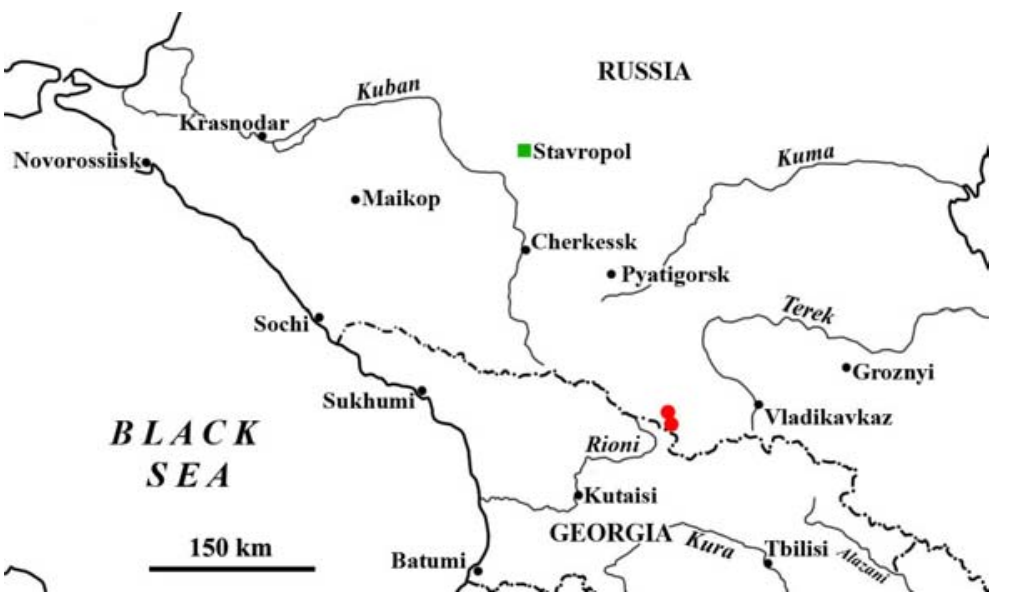

Map 1. Known distribution of Lithobius (Lithobius) dissimilis sp.n. (square) and Lithobius (Monotarsobius) evsyukovi sp.n. (circle). Map courtesy of A.P. Evsyukov.

Карта 1. Известное распространение Lithobius (Lithobius) dissimilis sp.n. (квадрат) и Lithobius (Monotarsobius) evsyukovi sp.n. (круг). Карта предоставлена с любезной помощью А.П. Евсюкова.

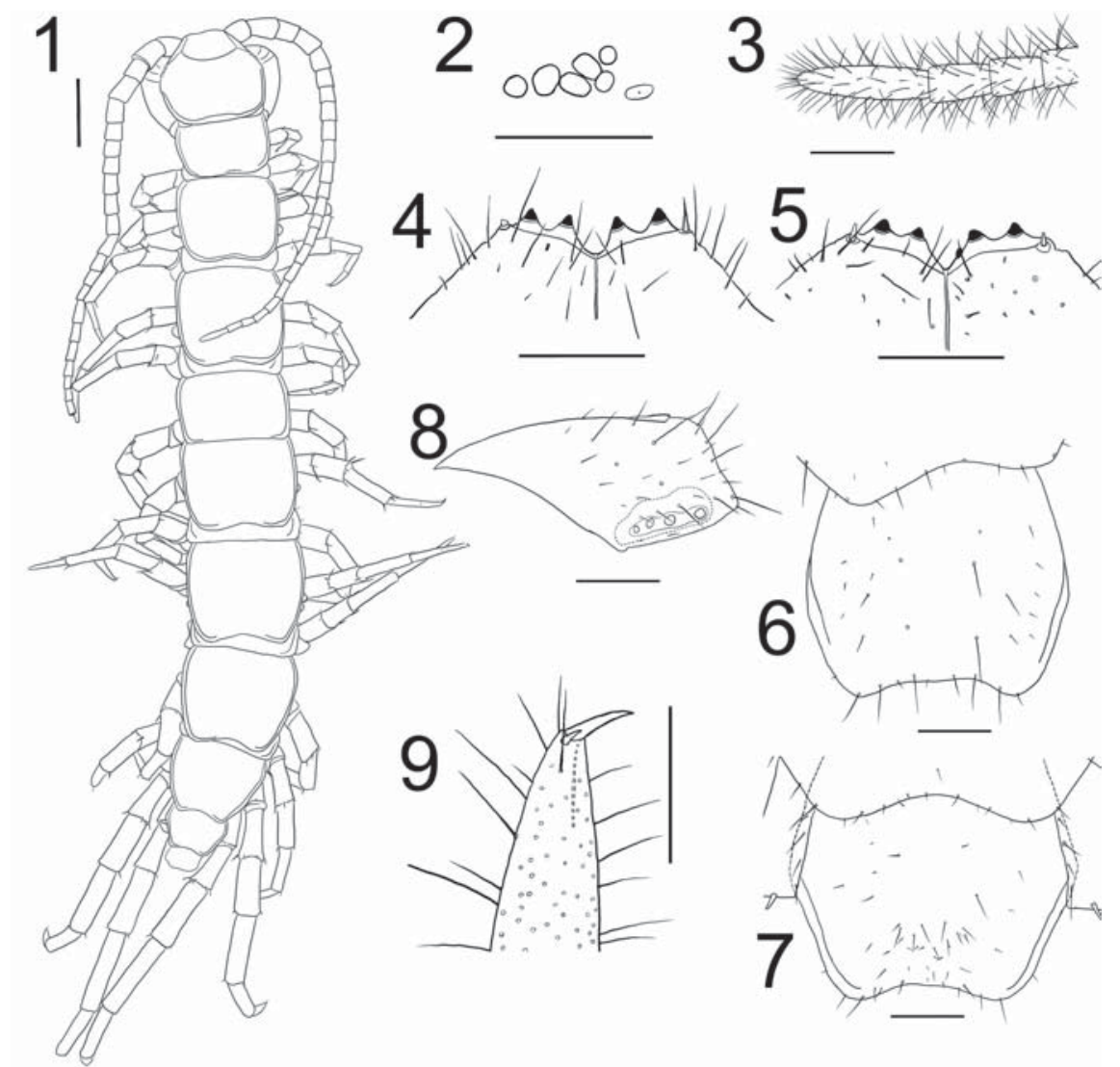

Figs 1-9. Diagnostic characters of Lithobius (Lithobius) dissimilis sp.n.: 1 - habitus, male, paratype; 2 - ocelli and Tömösváry's organ (pointed), holotype; 3 - ultimate antennomeres, holotype; 4 - anterior margin of forcipular coxosternite, holotype; 5 - anterior margin of forcipular coxosternite, paratype; 6 - intermediate tergite of female, holotype; 7 - intermediate tergite of male, paratype; 8 coxal pores of leg 15, holotype; $9-$ pretarsus of leg 15 , holotype. Scale bar: $1-1.0 \mathrm{~mm} ; 2-9-0.25 \mathrm{~mm}$.

Рис. 1-9. Диагностические признаки Lithobius (Lithobius) dissimilis sp.n.: 1 - общий вид, самец, паратип; 2 - глазки и Темешвариев орган, голотип; 3 - конечные членики антенны, голотип; 4 - передний край коксостернита ногочелюсти, голотип; 5 - передний край коксостернита ногочелюсти, паратип; 6 - промежуточный тергит, самка, голотип; 7 - промежуточный тергит, самец, паратип; 8 - коксальные поры 15 пары ног, голотип; 9 - коготь 15 пары ног, голотип. Масштаб: 1 - 1,0 мм; $2-$ $9-0,25$ мм. 


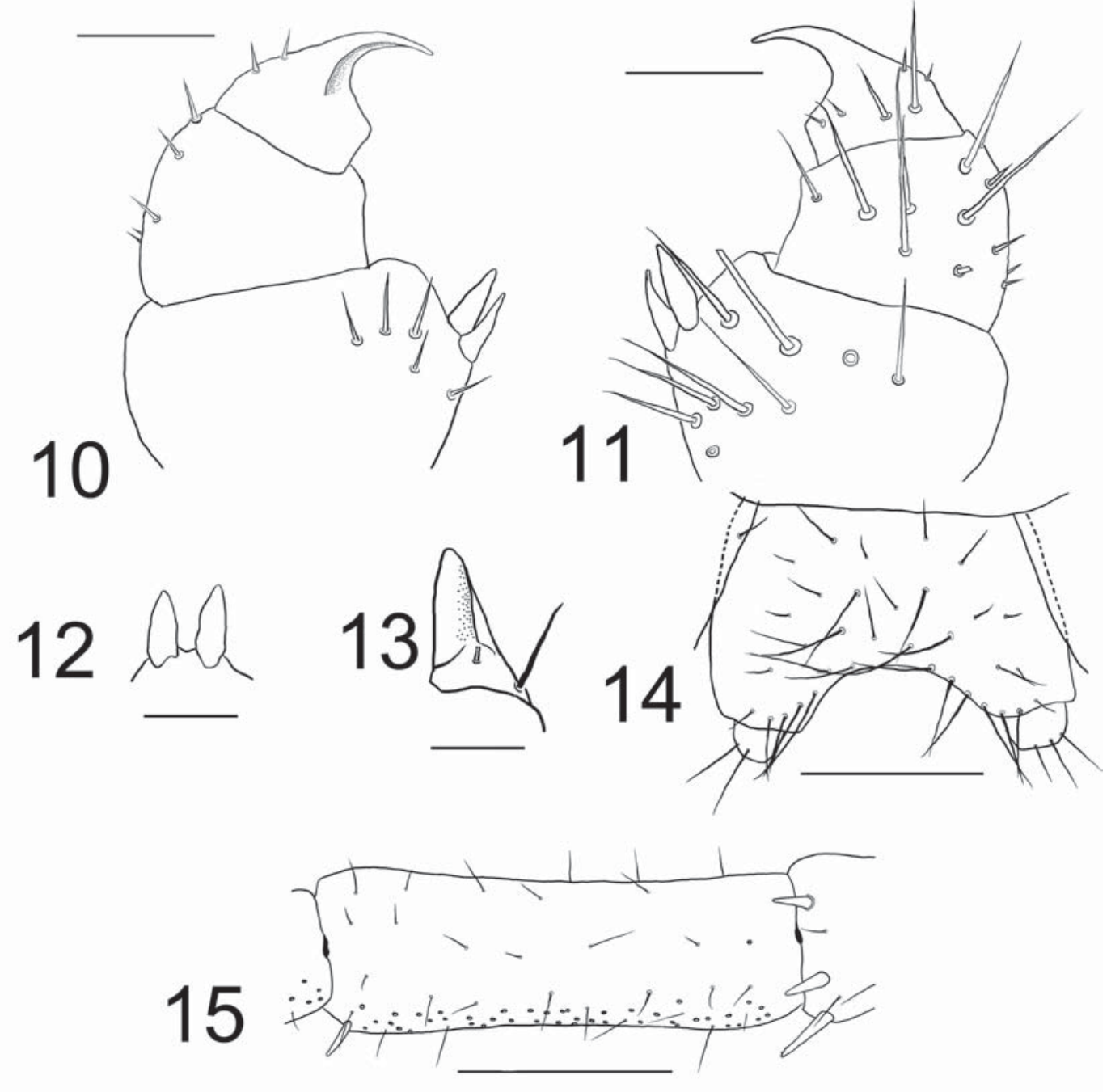

Figs 10-15. Diagnostic characters of Lithobius (Lithobius) dissimilis sp.n.: 10 - right female gonopod, mesal view, holotype; 11 right female gonopod, lateral view, holotype; 12 - spurs of female gonopod, ventral view, paratype; 13 - apical claw of female gonopod, ventral view, paratype; 14 - first genital sternite and gonopods of male, ventral view, paratype; 15 - femur 15 of male, dorsal view, paratype. Scale bar: $10-13-0.1 \mathrm{~mm} ; 14-0.25 \mathrm{~mm} ; 15-0.5 \mathrm{~mm}$.

Рис. 10-15. Диагностические признаки Lithobius (Lithobius) dissimilis sp.n.: 10 - правый гонопод самки, вид изнутри, голотип; 11 - правый гонопод самки, вид снаружи, голотип; 12 - шпоры гонопод самки, вид снизу, паратип; 13 - коготь гонопод самки, паратип; 14 - первый генитальный стернит и гоноподы самца, паратип; 15 - бедро пары ног 15 самца, вид сверху. Масштаб: $10-13-0,1$ мм; $14-0,25$ мм; $15-0,5$ мм.

composed of 23-27 articles; $1+3-5$ ocelli, arranged in two rows; anterior margin of forcipular coxosternite with $2+2$ teeth, with small shoulders, porodont setiform, posterolateral to lateral tooth; TT 9, 11 and 13 without posterior triangular projection; tergites densely setose; coxal pores 4-6, round; VaC absent; female gonopods with $2+2$ conical spurs, apical claw simple.

MATERIAL EXAMINED. Holotype $q$, Russia, North Caucasus, Stavropol Territory, near the city of Stavropol, Russian Forest, broadleaved forest, $600 \mathrm{~m}$ a.s.1., 10.V.2014, leg. R.V. Zuev. Paratypes. $1 \sigma^{7}, 3$ O $,, 3 \mathrm{sad} . O^{\top}, 2 \mathrm{sad}$. + , same locality as holotype, 6.VI.2014; 2 우, same locality, 26.IV.2015, all leg. R.V. Zuev.

DESCRIPTION. Holotype. Length: body ca 13 $\mathrm{mm}$ long, head $1.3 \mathrm{~mm}$ long, $1.4 \mathrm{~mm}$ wide; $1.55 \mathrm{~mm}$ broad at $\mathrm{T} \mathrm{10}$; legs 14 and 15, 4.0 and $5.0 \mathrm{~mm}$ long, respectively (Fig. 1). Right gonopod dissected and placed together with the holotype.

Colour (in alcohol after 2 years of preservation): generally yellow; legs 14 and 15, TT 1, 14 and 15 darker; cephalic plate and antennae light brown.

Cephalic plate: smooth and sparsely setose dorsally, slightly broader than long, broader than $\mathrm{T} 1$; posterior margin straight; marginal ridge with a medial thickening.

Ocelli: $1+3,2$ on each side, slightly pigmented, subcircular, posterior ocellus subcircular, not contiguous with secondary ocelli; posterosuperior ocellus larger than posterior ocellus and other seriated ocelli (Fig. 2). 
Table 1. Lithobius (Lithobius) dissimilis sp.n. (holotype): plectrotaxy; spines in brackets are asymmetric. Таблица 1. Lithobius (Lithobius) dissimilis sp.n. (голотип): плектротаксия; шипы в скобках ассиметричны.

\begin{tabular}{|c|c|c|c|c|c|c|c|c|c|}
\hline \multirow{2}{*}{ Leg pairs } & \multicolumn{5}{|c|}{ Ventral } & \multicolumn{4}{|c|}{ Dorsal } \\
\hline & $\mathrm{C}$ & $\operatorname{Tr}$ & $\mathrm{P}$ & $\mathrm{F}$ & $\mathrm{t}$ & $\mathrm{C}$ & $\mathrm{P}$ & F & $\mathrm{t}$ \\
\hline 1 & - & - & $\mathrm{mp}$ & amp & $\mathrm{am}$ & - & $\mathrm{mp}$ & $\mathrm{a}$ & $\mathrm{a}$ \\
\hline 2 & - & - & $\mathrm{mp}$ & amp & $\mathrm{am}$ & - & $\mathrm{mp}$ & $\mathrm{a} p$ & $\mathrm{a}$ \\
\hline 3 & - & - & $\mathrm{mp}$ & amp & $\mathrm{am}$ & - & $\mathrm{mp}$ & $\mathrm{a} p$ & $\mathrm{a}$ \\
\hline 4 & - & - & $\mathrm{mp}$ & amp & $\mathrm{am}$ & - & $\mathrm{mp}$ & $\mathrm{a} \quad \mathrm{p}$ & $\mathrm{a} \quad \mathrm{p}$ \\
\hline 5 & - & - & $\mathrm{mp}$ & amp & $\mathrm{am}$ & - & amp & $\mathrm{a} p$ & $\mathrm{a} p$ \\
\hline 6 & - & - & $\mathrm{mp}$ & amp & $\mathrm{am}$ & - & amp & a $p$ & $\mathrm{a} p$ \\
\hline 7 & - & - & $\mathrm{mp}$ & amp & $\mathrm{am}$ & - & amp & $\mathrm{a} \mathrm{p}$ & $\mathrm{a} p$ \\
\hline 8 & - & - & $\mathrm{mp}$ & amp & am & - & amp & $\mathrm{a} p$ & $\mathrm{a} p$ \\
\hline 9 & - & - & amp & amp & $\mathrm{am}$ & - & amp & $\mathrm{a} p$ & $\mathrm{a} p$ \\
\hline 10 & - & - & amp & amp & $\mathrm{am}$ & - & amp & $\mathrm{a} p$ & $\mathrm{a} p$ \\
\hline 11 & - & - & amp & amp & am & - & amp & $\mathrm{a} p$ & $\mathrm{a} p$ \\
\hline 12 & - & $\mathrm{m}$ & amp & amp & $\mathrm{am}$ & - & amp & $\mathrm{a} p$ & $\mathrm{a} \quad \mathrm{p}$ \\
\hline 13 & - & $\mathrm{m}$ & amp & amp & $\mathrm{am}$ & (a) & amp & $\mathrm{a} p$ & (a) $p$ \\
\hline 14 & - & $\mathrm{m}$ & amp & amp & $\mathrm{am}$ & - & amp & $\mathrm{p}$ & $\mathrm{p}$ \\
\hline 15 & - & $\mathrm{m}$ & $\mathrm{amp}$ & $\mathrm{am}$ & - & $\mathrm{a}$ & amp & $\mathrm{p}$ & - \\
\hline
\end{tabular}

Table 2. Lithobius (Lithobius) dissimilis sp.n. (paratypes): plectrotaxy; variable spines are in brackets. Таблица 2. Lithobius (Lithobius) dissimilis sp.n. (паратипы): плектротаксия; вариабельные шипы в скобках.

\begin{tabular}{|c|c|c|c|c|c|c|c|c|c|}
\hline \multirow{2}{*}{ Leg pairs } & \multicolumn{5}{|c|}{ Ventral } & \multicolumn{4}{|c|}{ Dorsal } \\
\hline & $\mathrm{C}$ & $\operatorname{Tr}$ & $\mathrm{P}$ & $\mathrm{F}$ & $\mathrm{t}$ & $\mathrm{C}$ & $\mathrm{P}$ & $\mathrm{F}$ & $\mathrm{t}$ \\
\hline 1 & - & - & $\mathrm{mp}$ & $\mathrm{amp}$ & am & - & (a)mp & $a(p)$ & $\mathrm{a}$ \\
\hline 2 & - & - & $\mathrm{mp}$ & amp & $\mathrm{am}$ & - & (a)mp & $\mathrm{a} p$ & $\mathrm{a}$ \\
\hline 3 & - & - & $\mathrm{mp}$ & $\mathrm{amp}$ & am & - & (a)mp & $\mathrm{a} p$ & $a(p)$ \\
\hline 4 & - & - & $\mathrm{mp}$ & amp & am & - & (a)mp & $\mathrm{a} p$ & $\mathrm{a} p$ \\
\hline 5 & - & - & $\mathrm{mp}$ & $\mathrm{amp}$ & am & - & $\mathrm{amp}$ & $\mathrm{a} p$ & $\mathrm{a} p$ \\
\hline 6 & - & $\overline{-}$ & (a)mp & amp & $\mathrm{am}$ & - & $\mathrm{amp}$ & $\mathrm{a} \quad \mathrm{p}$ & $\mathrm{a} \quad \mathrm{p}$ \\
\hline 7 & - & - & (a)mp & $\mathrm{amp}$ & $\mathrm{am}$ & - & $\mathrm{amp}$ & $\mathrm{a} p$ & $\mathrm{a} p$ \\
\hline 8 & - & - & (a)mp & amp & am & - & $\mathrm{amp}$ & $\mathrm{a} p$ & a p \\
\hline 9 & - & - & $\mathrm{amp}$ & amp & am & - & $\mathrm{amp}$ & $\mathrm{a} p$ & $\mathrm{a} p$ \\
\hline 10 & - & - & amp & amp & am & - & amp & $\mathrm{a} p$ & $\mathrm{a} p$ \\
\hline 11 & - & - & amp & amp & am & - & amp & $\mathrm{a} \quad \mathrm{p}$ & $\mathrm{a} \quad \mathrm{p}$ \\
\hline 12 & - & (m) & amp & amp & $\mathrm{am}$ & - & $\mathrm{amp}$ & $\mathrm{a} \quad \mathrm{p}$ & $\mathrm{a} \quad \mathrm{p}$ \\
\hline 13 & - & $\mathrm{m}$ & $\mathrm{amp}$ & amp & am & (a) & $\mathrm{amp}$ & (a) $\mathrm{p}$ & (a) $p$ \\
\hline 14 & - & $\mathrm{m}$ & amp & amp & $\mathrm{am}$ & (a) & amp & $\mathrm{p}$ & $\bar{p}$ \\
\hline 15 & - & $\mathrm{m}$ & $\mathrm{amp}$ & am & (a) & $\mathrm{a}$ & $\mathrm{amp}$ & $\mathrm{p}$ & - \\
\hline
\end{tabular}

Tömösváry's organ: oval, almost size of the nearest secondary ocellus (see Fig. 2).

Antennae: ca $7.0 \mathrm{~mm}$ long, almost reaching $\mathrm{T} 8$ when folded backwards, ca $54 \%$ the length of body, composed of 23 articles (both left and right sides), the first two basal articles large, first basal article almost as long as broad, the next ones are longer than broad, last article about 2 times as long as penultimate one (Fig. 3 ); articles densely clothed with setae.

Forcipular segment: coxosternite subhexagonal, anterior margin narrow, teeth conical, equal in size, $2+2$, median diastrema (= notch) wide, U-shaped; free margin of coxosterinte with small shoulders; porodont setiform, lying posterolateral to lateral tooth, base of por- 
Table 3. Diagnostic characters of Lithobius integrior (Chamberlin, 1952), L. ispartensis Zapparoli, 1999 and $L$. dissimilis sp.n.

Таблица 3. Диагностические признаки Lithobius integrior (Chamberlin, 1952), L. ispartensis Zapparoli, 1999 и L. dissimilis sp.n.

\begin{tabular}{|l|l|l|l|}
\hline & L. integrior & L. ispartensis & L. dissimilis \\
\hline Body coloration & chestnut & chestnut & yellow \\
\hline Body size (mm) & 12.0 & $12.0-13.0$ & $13.0-16.0$ \\
\hline Number of antennal articles & $46-47$ & $26-28$ & $23-27$ \\
\hline Number of ocelli & $1+11$ & $1+6-7$ & $1+3-5$ \\
\hline Number of coxal pores & $3-4$ & $2-3$ & $4-6$ \\
\hline $\begin{array}{l}\text { First article of female } \\
\text { gonopods }\end{array}$ & $\begin{array}{l}\text { with 2+2 short } \\
\text { cilindroconical spurs, with 5 } \\
\text { dorsomedial setae }\end{array}$ & $\begin{array}{l}\text { with 2+2 long spurs, } \\
\text { without dorsomedial setae }\end{array}$ & $\begin{array}{l}\text { with 2+2 long } \\
\text { cilindroconical spurs, with 5 } \\
\text { dorsomedial setae }\end{array}$ \\
\hline $\begin{array}{l}\text { Second article of female } \\
\text { gonopods }\end{array}$ & with 6 dorsolateral setae & with 5 dorsolateral setae & with 5-7 dorsolateral setae \\
\hline Apical claw & $\begin{array}{l}\text { unidentate, short, without } \\
\text { dorsolateral setae }\end{array}$ & $\begin{array}{l}\text { unidentate, long, with 2 } \\
\text { dorsolateral setae }\end{array}$ & $\begin{array}{l}\text { unidentate, long, with 2-3 } \\
\text { dorsolateral setae }\end{array}$ \\
\hline
\end{tabular}

odont distinct (Fig. 4); long to short setae sparse in anterior part of ventral surface of coxosternite. Distal part of tarsungulum about 2 times as long as proximal part. Trochanteroprefemur, femur, tibia and proximal part of tarsungulum fringed with few setae.

Tergites: smooth and densely setose, especially near margins; T 1 subtrapeziform, slightly narrower than T 3 , lateral margins convergent posteriorly, posterior angles rounded, posterior margin slightly sinuate; TT 3 , $5,7,8,10,12$ subrectangular, elongated; lateral margins of TT 3, 5, 7 subparallel, of TT 8, 10, 12 slightly convergent posteriorly, T 14 clearly convergent posteriorly; posterior angles of TT $3,5,8,10,12,14$ rounded, of T 7 angulate. Posterior margin of TT 3, 5, 8, 10, 12, 14 sinuate, of T 7 straight; lateral margins of TT 2, 4, 6 subparallel, posterior angles of TT 2, 4 blunt, of T 6 angulate, posterior margin of TT 2, 4, 6 straight; posterior angles of TT 9, 11 blunt, of T 13 angulate, TT 9, 11 and 13 without triangular projections; intermediate tergite elongated, lateral margins convex, posterior angles rounded, posterior margin sinuate (Fig. 6).

Sternites: smooth, subtrapeziform, posterior side narrower than anterior one, posterior margins almost straight; setation rare, S 14, 15 more densely setose.

Legs: tarsal articulation defined on legs 1-13; legpairs 14 and 15 longer and thicker than 1-13; leg 15 longest of all; pretarsus of legs 1-14 with a slightly curved, long, principal claw $(0.14 \mathrm{~mm}$ on leg 8$)$ and smaller and thinner anterior and posterior accessory spines, anterior accessory spines long and slender, ca 0.4 the length of principal claw, posterior one slightly stronger, ca 0.4 the length of principal claw. Pretarsus of leg 15 with a small, accessory, apical claw (ca 0.4 the length of principal claw) (Fig. 9); abundant glandular pores on inner surfaces of prefemur, femur, tibia and tarsus of legs 14 and 15; short to comparatively long setae scattered very sparsely over surface of all podomeres of all legs; tarsus 1 and tarsus 2 of legs $1-$ 13 with combs of setae, almost regularly arranged in two rows: anterior row comprising 14-18 setae, posterior row of 6-9 setae. Plectrotaxy: as in Table 1.
Coxal pores (Fig. 8): 4,5,5,4 on both the left and right sides, arranged in a single regular row, circular, separated from one another by a space greater than their own diameter; coxal pore field set in a relatively shallow groove.

Female first genital sternite wider than long, 13-15 regularly scattered setae on each side; posterior margin with a short, posterior, truncate expansion between condyles of gonopods.

Female gonopods (Figs 10-13): first article fairly broad, bearing nine long setae arranged in two irregular rows, $2+2$ conical spurs (Fig. 11) very close to each other, internal spur smaller and shorter than external one (Fig. 12), a row of five, medium, dorsomedian setae positioned near insertion of spurs (Fig. 10). Second article with seven medium to long setae arranged in two irregular rows on its ventral side, five dorsolateral setae in a line. Apical claw strongly curved, narrow, without lateral denticles (Fig. 13); four short to medium setae situated at base of claw; two short dorsolateral setae in a line.

Male. Intermediate tergite: wider than that of female, subhexagonal, lateral margins convergent anteriorly and posteriorly, posterior angles rounded, posterior margin sinuate, in posterior third densely covered with short and medium-sized setae (Fig. 7).

Male first genital sternite: posterior margin sinuate, posterior angles rounded, 34 short to medium setae scattered sparsely over its surface and at lateral margins (Fig. 14).

Male gonopods: small, one-segmented, with 2-3 apical setae (see Fig. 14).

Male legs 14 and 15 almost same in size as those of female. Anterior part of femur 15 slightly swollen (Fig. 15).

Variation. The other adult specimens examined differ from the holotype in the following characters. Length: body 14-16 mm long, $1.8-1.9 \mathrm{~mm}$ broad at $\mathrm{T}$ 10; legs 14 and $15 \mathrm{ca} 5.0 \mathrm{~mm}$ and $6.0 \mathrm{~mm}$ long, respectively. Ocelli: $1+2,2,1+2,1$. Antennae: ca $8 \mathrm{~mm}$ long, composed of 23-27 articles. Forcipular segment: cox- 


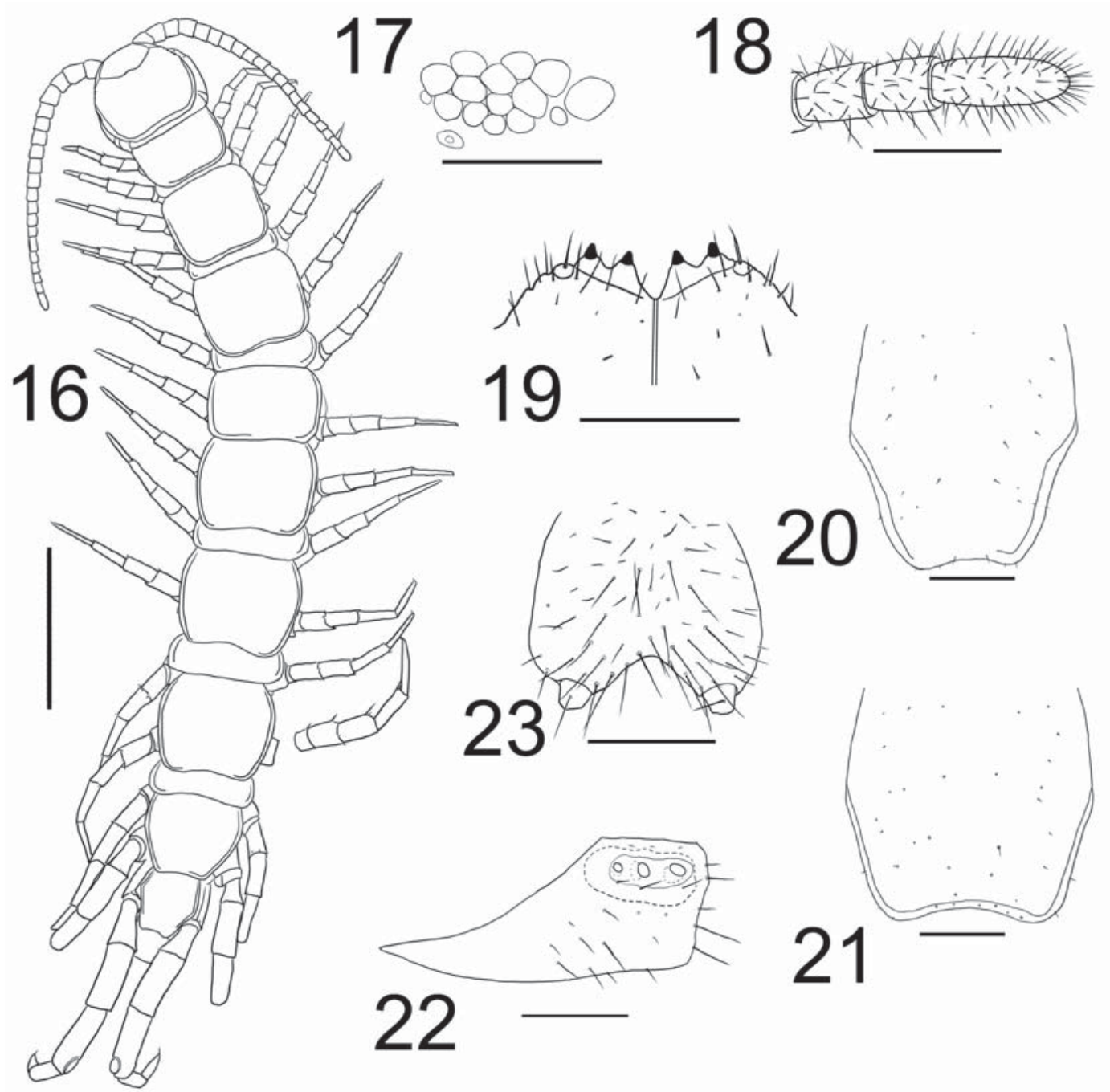

Figs 16-23. Diagnostic characters of Lithobius (Monotarsobius) evsyukovi sp.n.: 16 — habitus, male, holotype; 17 — ocelli, holotype; 18 - ultimate antennomeres, holotype; 19 - anterior margin of forcipular coxosternite, holotype; 20 - intermediate tergite of male, holotype; 21 - intermediate tergite of female, paratype; 22 - coxal pores of leg 15 , holotype; 23 - first genital sternite and gonopods of male, ventral view, holotype. Scale bar: $16-2.0 \mathrm{~mm} ; 17-23-0.25 \mathrm{~mm}$.

Рис. 16-23. Диагностические признаки Lithobius (Monotarsobius) evsyukovi sp.n.: 16 - общий вид, самец, голотип; 17 глазки, голотип; 18 - конечные членики антенны, голотип; 19 - передний край коксостернита ногочелюсти, голотип; $20-$ промежуточный тергит, самец, голотип; 21 - промежуточный тергит, самка, паратип; 22 - коксальные поры 15 пары ног, голотип; $23-$ первый генитальный стернит и гоноподы самца, голотип. Масштаб: $16-2,0$ мм; 17-23 - 0,25 мм.

osternal teeth $2+3$, additional teeth smaller than others and situated inside them (Fig. 5). Plectrotaxy: as in Table 2. Coxal pores: 5,5,4,4; 5,6,6,5. Female gonopods: with $2+3$ spurs, three small dorsolateral setae on apical claw.

NAME. In Latin, "dissimilis" means "unlike". This species differs from all other Lithobius species known from the Caucasus.

GENERAL DISTRIBUTION: North Caucasus.

CHOROTYPE: Stavropol upland, endemic?

HABITATS: broadleaf forest with Carpinus and Quercus.

ALTITUDINAL RANGE: $600 \mathrm{~m}$.
REMARKS: L. dissimilis sp.n. is close to L. integrior (Chamberlin, 1952) and L. ispartensis Zapparoli, 1999, both from Turkey, by the following characteristics: lack of triangular projections on tergites, $2+2$ teeth on forcipular coxosternite, additional claw on leg 15 , and also in structure of the female gonopods [Chamberlin, 1952; Zapparoli, 1994, 1999]. The main differences between these species are presented in Table 3 .

Lithobius (Monotarsobius) evsyukovi sp.n.

Figs 16-30.

DIAGNOSIS: A small to medium-sized Lithobius $(8.5-13 \mathrm{~mm})$, antennae ca $29 \%$ the length of body, 

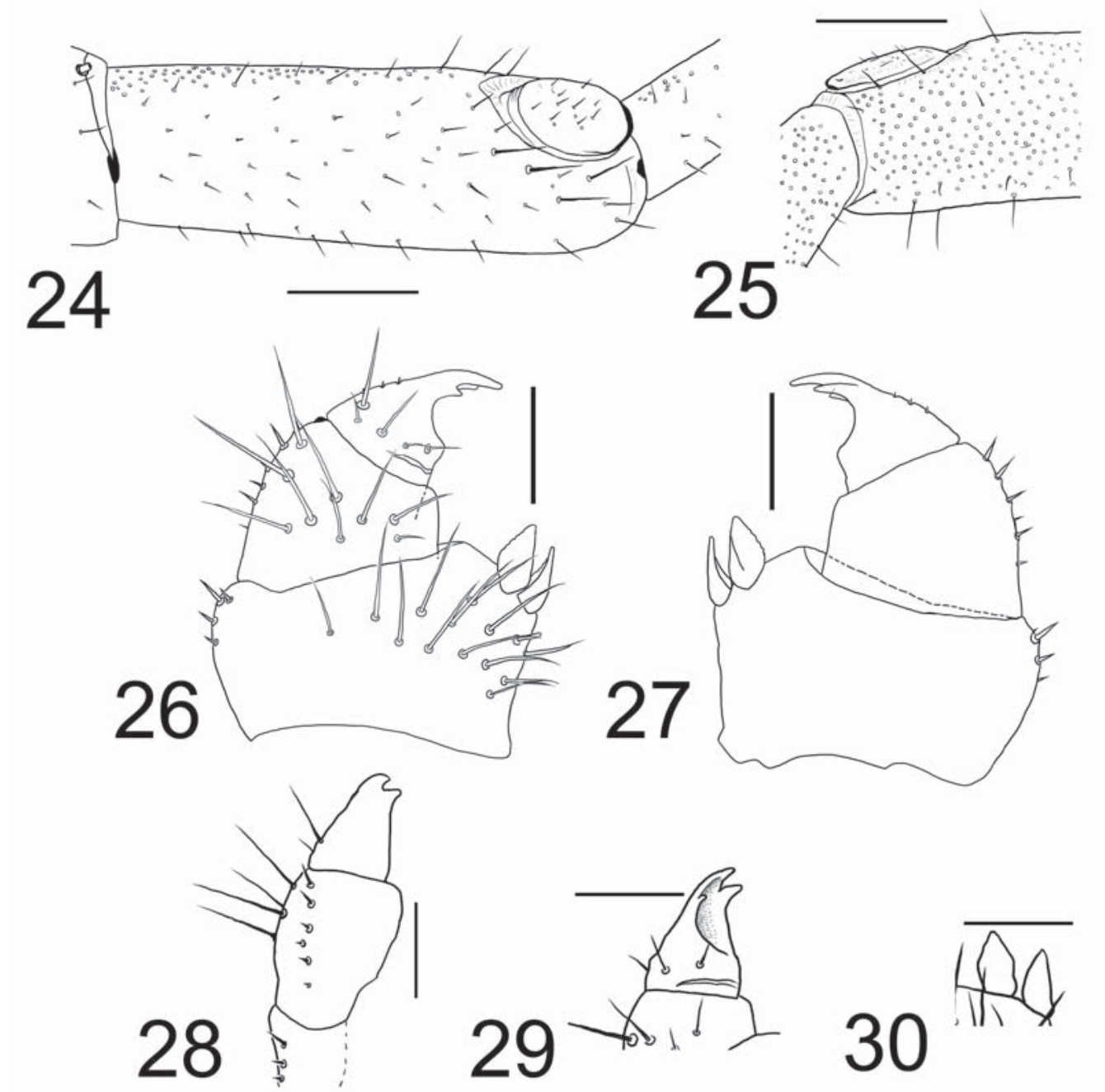

Figs 24-30. Diagnostic characters of Lithobius (Monotarsobius) evsyukovi sp.n.: 24 - tibia 15 of male, dorsal view, holotype; 25 distal part of tibia 15 of male, lateral view, holotype; 26 - left female gonopod, lateral view, paratype; 27 - left female gonopod, mesal view, paratype; 28 - right female gonopod, dorsal view, paratype; 29 - apical claw of female gonopod, ventral view, paratype; 30 spurs of female gonopod, ventral view, paratype. Scale bar: $24-25-0.25 \mathrm{~mm}$; $26-30-0.1 \mathrm{~mm}$.

Рис. 24-30. Диагностические признаки Lithobius (Monotarsobius) evsyukovi sp.n.: 24 - голень 15 пары ног самца, вид сверху, голотип; 25 - дистальная часть голени 15 пары ног самца, вид сбоку, голотип; 26 - левый гонопод самки, вид сбоку, паратип; 27 - левый гонопод самки, вид изнутри, паратип; 28 - правый гонопод самки, вид со спины, паратип; 29 - коготь гонопода самки, вид снизу, паратип; $30-$ шпоры гонопод самки, вид снизу, паратип. Масштаб: 24-25 - 0,25 мм; 26-30-0,1 мм.

composed of 18-21 articles (usually 20); 1+9-14 ocelli arranged in 3-4 rows; anterior margin of forcipular coxosternite with $2+2$ teeth, with shoulders, porodont setiform, posterolateral to lateral tooth; TT 9, 11 and 13 without posterior triangular projection; tergites clothed with short and thin setae; coxal pores 3-5, round; $\mathrm{VaC}$ absent; female gonopods with $2+2$ conical spurs, 2-4 dorsolateral setae on first article, apical claw tridentate.

MATERIAL EXAMINED. Holotype $\sigma^{7}$, Russia, North Caucasus, North Ossetia-Alania, Irafsky Distr., canyon of Tanandon River, eastern exposition, alpine zone, $2100 \mathrm{~m}$ a.s.l., 9.VIII.2010, leg. A.P. Evsyukov. - Paratypes $10^{\top}, 2$ ㅇ, same data as holotype; $10^{\top}$, canyon of Kharesidon River, Mount Matsuta, eastern exposition, hazel thickets, $1850 \mathrm{~m}$ a.s.1., 11.VIII.2010, all leg. A.P. Evsyukov.

DESCRIPTION. Holotype. Length: body ca 12 $\mathrm{mm}$ long, head $1.2 \mathrm{~mm}$ long, $1.3 \mathrm{~mm}$ wide; $1.5 \mathrm{~mm}$ broad at T 10; legs 14 and 15, 3.0 and $3.5 \mathrm{~mm}$, respectively (Fig. 16).

Colour (in alcohol after 6 years of preservation): generally brown; legs 14 and 15, TT 14, 15 and cephalic plate darker.

Cephalic plate: smooth and sparsely setose dorsally, slightly broader than long, slightly broader than $\mathrm{T} 1$; posterior margin slightly sinuate; marginal ridge with a medial thickening. 
Table 4. Lithobius (Monotarsobius) evsyukovi sp.n. (holotype): plectrotaxy; spines in brackets are asymmetric. Таблица 4. Lithobius (Monotarsobius) evsyukovi sp.n. (голотип): плектротаксия; шипы в скобках ассиметричны.

\begin{tabular}{|c|c|c|c|c|c|c|c|c|c|}
\hline \multirow{2}{*}{ Leg pairs } & \multicolumn{5}{|c|}{ Ventral } & \multicolumn{4}{|c|}{ Dorsal } \\
\hline & $\mathrm{C}$ & $\operatorname{Tr}$ & $\mathrm{P}$ & $\mathrm{F}$ & $\mathrm{t}$ & $\mathrm{C}$ & $\mathrm{P}$ & $\mathrm{F}$ & $\mathrm{t}$ \\
\hline 1 & - & - & $\mathrm{p}$ & amp & $\mathrm{m}$ & - & $\mathrm{a} p$ & $\mathrm{a} p$ & $\mathrm{a}$ \\
\hline 2 & - & - & $\mathrm{mp}$ & $\mathrm{amp}$ & am & - & $\mathrm{a} \quad \mathrm{p}$ & $\mathrm{a} p$ & a p \\
\hline 3 & - & - & $\mathrm{mp}$ & amp & am & - & $\mathrm{a} \quad \mathrm{p}$ & $\mathrm{a} \quad \mathrm{p}$ & a p \\
\hline 4 & - & - & $\mathrm{mp}$ & amp & am & - & $\mathrm{a} \quad \mathrm{p}$ & $\mathrm{a} \quad \mathrm{p}$ & $\mathrm{a} \quad \mathrm{p}$ \\
\hline 5 & - & - & $\mathrm{mp}$ & amp & am & - & $\mathrm{a} p$ & $\mathrm{a} \quad \mathrm{p}$ & $\mathrm{a} p$ \\
\hline 6 & - & - & $\mathrm{mp}$ & amp & $\mathrm{am}$ & - & $\mathrm{a} \quad \mathrm{p}$ & $\mathrm{a} \quad \mathrm{p}$ & $\mathrm{a} p$ \\
\hline 7 & - & - & $\mathrm{mp}$ & amp & am & - & a p & $\mathrm{a} \quad \mathrm{p}$ & a p \\
\hline 8 & - & - & $\mathrm{mp}$ & $\mathrm{amp}$ & am & - & $\mathrm{a} p$ & $\mathrm{a} \quad \mathrm{p}$ & $\mathrm{a} p$ \\
\hline 9 & - & - & $\mathrm{mp}$ & amp & am & - & amp & $\begin{array}{ll}\mathrm{a} & \mathrm{p}\end{array}$ & $\mathrm{a} p$ \\
\hline 10 & - & - & $\mathrm{mp}$ & amp & am & - & amp & $\mathrm{a} \quad \mathrm{p}$ & $\mathrm{a} p$ \\
\hline 11 & - & $\mathrm{m}$ & $\mathrm{mp}$ & amp & $\mathrm{am}$ & - & amp & $\mathrm{a} \quad \mathrm{p}$ & $\mathrm{a} p$ \\
\hline 12 & - & $\mathrm{m}$ & amp & amp & am & (a) & amp & $\mathrm{p}$ & $\mathrm{p}$ \\
\hline 13 & - & $\mathrm{m}$ & amp & amp & $\mathrm{am}$ & $\mathrm{a}$ & amp & $\mathrm{p}$ & $\mathrm{p}$ \\
\hline 14 & - & $\mathrm{m}$ & amp & amp & $\mathrm{m}$ & $\mathrm{a}$ & amp & $\mathrm{p}$ & $\mathrm{p}$ \\
\hline 15 & - & $\mathrm{m}$ & amp & $\mathrm{am}$ & - & $\mathrm{a}$ & amp & $\mathrm{p}$ & - \\
\hline
\end{tabular}

Ocelli: $1+2,4,4,4$ on left side (Fig. 17) and 1+3,4,3,2 on right side, pigmented, subcircular, unequal in size, posterior ocellus oval, larger than posterosuperior ocellus and other seriate ocelli, not contiguous with secondary ocelli.

Tömösváry’s organ: oval, almost the size of the nearest secondary ocellus (see Fig. 17).

Antennae: ca $3.5 \mathrm{~mm}$ long, reaching $\mathrm{T} 5$ when folded backwards, ca $29 \%$ the length of body, composed of 20 articles (both left and right sides), the first two basal articles large, first basal article almost as long as broad, next ones longer than broad, last article about 2 times as long as penultimate one (Fig. 18); articles densely clothed with setae.

Forcipular segment: coxosternite subhexagonal, anterior margin narrow, teeth conical, equal in size, $2+2$, median diastrema wide, U-shaped; free margin of coxosterinte with shoulders; porodont setiform, lying posterolateral to lateral tooth; base of porodont distinct (Fig. 19); long to short setae sparse in anterior part of ventral surface of coxosternite. Distal part of tarsungulum ca 3 times as long as proximal part. Trochanteroprefemur, femur, tibia and proximal part of tarsungulum fringed with few setae.

Tergites: almost smooth, covered with short and thin setae; $\mathrm{T} 1$ subtrapeziform, narrower than $\mathrm{T}$ 3, lateral margins convergent posteriorly, posterior angles rounded, posterior margin slightly sinuate, in TT $3,5,7,8,10,12$ subrectangular, broader than long; lateral margins of TT 3, 5, 7 subparallel, of TT 8, 10,
12 slightly convergent posteriorly, of T 14 clearly convergent posteriorly; posterior angles of TT 3, 5, 7, 8, $10,12,14$ rounded; posterior margin of TT 3,5 slightly sinuate, of TT 7, 14 almost straight, of TT 8, 10, 12 sinuate; lateral margins of TT 2, 4, 6 subparallel, posterior angles of TT 2, 4, 6 blunt, posterior margin of TT 2, 4, 6 straight; posterior angles of T 9, 11, 13 blunt, of TT 9, 11 and 13 without triangular projections. Intermediate tergite elongated, lateral margins convex, posterior angles rounded, posterior margin sinuate (Fig. 20).

Sternites: smooth, subtrapeziform, posterior side narrower than anterior one, posterior margins almost straight; setation sparse, S 14, 15 more densely setose.

Legs: tarsi 1-13 fused, articulation between tarsomeres absent, but a strip of bright chitin in its place there; leg-pairs 13-15 longer and thicker than 1-12; leg 15 longest; pretarsi 1-14 with a slightly curved, long, principal claw $(0.11 \mathrm{~mm}$ long on leg 13$)$, as well as smaller and thinner anterior and posterior accessory spines, anterior accessory spines long and slender, ca 0.4 the length of principal claw, posterior one slightly stronger, ca 0.3 the length of principal claw. Pretarsus 15 without accessory apical claw; abundant glandular pores on inner surfaces of prefemora, femora, tibiae and tarsi 14 and 15; short to comparatively long setae scattered very sparsely over entire surface of all podomeres of all legs. Tibia 15 in distodorsal part with a fairly large, flat, ovoid wart, slightly sloping back, supporting a few short setae at apex (Figs $24 \& 25$ ). Plectrotaxy: as in Table 4. 
Table 5. Lithobius (Monotarsobius) evsyukovi sp.n. (paratypes): plectrotaxy; variable spines are in brackets. Таблица 5. Lithobius (Monotarsobius) evsyukovi sp.n. (паратипы): плектротаксия; вариабельные шипы в скобках.

\begin{tabular}{|c|c|c|c|c|c|c|c|c|c|}
\hline \multirow{2}{*}{ Leg pairs } & \multicolumn{5}{|c|}{ Ventral } & \multicolumn{4}{|c|}{ Dorsal } \\
\hline & $\mathrm{C}$ & $\mathrm{Tr}$ & $\mathrm{P}$ & $\mathrm{F}$ & $\mathrm{t}$ & $\mathrm{C}$ & $\mathrm{P}$ & $\mathrm{F}$ & $\mathrm{t}$ \\
\hline 1 & - & - & $\mathrm{p}$ & amp & (a)m & - & $\mathrm{p}$ & $\mathrm{a}(\mathrm{p})$ & $\mathrm{a}$ \\
\hline 2 & - & - & (m)p & amp & $\mathrm{am}$ & - & $\mathrm{a} \quad \mathrm{p}$ & $\mathrm{a} \quad \mathrm{p}$ & $\mathrm{a} \mathrm{p}$ \\
\hline 3 & - & - & (m)p & amp & $\mathrm{am}$ & - & $\mathrm{a} \quad \mathrm{p}$ & $\mathrm{a} \quad \mathrm{p}$ & $\mathrm{a} \mathrm{p}$ \\
\hline 4 & - & - & $(\mathrm{m}) \mathrm{p}$ & amp & $\mathrm{am}$ & - & $\mathrm{a} \quad \mathrm{p}$ & $\mathrm{a} \quad \mathrm{p}$ & a p \\
\hline 5 & - & - & (m)p & amp & $\mathrm{am}$ & - & $\mathrm{a} \quad \mathrm{p}$ & $\mathrm{a} \quad \mathrm{p}$ & $\mathrm{a} p$ \\
\hline 6 & - & - & (m)p & amp & $\mathrm{am}$ & - & $\mathrm{a} \quad \mathrm{p}$ & $\mathrm{a} \quad \mathrm{p}$ & $\mathrm{a} \mathrm{p}$ \\
\hline 7 & - & - & $\mathrm{mp}$ & amp & $\mathrm{am}$ & - & $\mathrm{a} \quad \mathrm{p}$ & $\mathrm{a} \quad \mathrm{p}$ & $\mathrm{a} \mathrm{p}$ \\
\hline 8 & - & - & $\mathrm{mp}$ & amp & am & - & $\mathrm{a} \quad \mathrm{p}$ & $\mathrm{a} \quad \mathrm{p}$ & $\mathrm{a} p$ \\
\hline 9 & - & - & $\mathrm{mp}$ & amp & $\mathrm{am}$ & - & amp & $\mathrm{a} p$ & a p \\
\hline 10 & - & - & $\mathrm{mp}$ & amp & $\mathrm{am}$ & - & $\mathrm{am}(\mathrm{p})$ & $\mathrm{a} \quad \mathrm{p}$ & $\mathrm{a} \mathrm{p}$ \\
\hline 11 & - & (m) & $\mathrm{mp}$ & amp & am & - & amp & (a) $p$ & $\mathrm{a} p$ \\
\hline 12 & - & (m) & amp & amp & $\mathrm{am}$ & (a) & amp & $\mathrm{p}$ & $\mathrm{p}$ \\
\hline 13 & - & (m) & amp & amp & $\mathrm{am}$ & $\mathrm{a}$ & amp & $\mathrm{p}$ & $\mathrm{p}$ \\
\hline 14 & - & $\mathrm{m}$ & amp & amp & $\mathrm{m}$ & $\mathrm{a}$ & amp & $\mathrm{p}$ & $\mathrm{p}$ \\
\hline 15 & - & $\mathrm{m}$ & amp & $\mathrm{am}$ & - & $\mathrm{a}$ & amp & $\mathrm{p}$ & - \\
\hline
\end{tabular}

Table 6. Diagnostic characters of Lithobius turkestanicus Attems, 1904, Lithobius ferganensis (Trotzina, 1894), L. sseliwanoffi Garbowski, 1897 and L. evsyukovi sp.n. Таблица 6. Диагностические признаки Lithobius turkestanicus Attems, 1904, Lithobius ferganensis (Trotzina, 1894), L. sseliwanoffi Garbowski, 1897 и L. evsyukovi sp.n.

\begin{tabular}{|l|l|l|l|l|}
\hline & L.turkestanicus & L.ferganensis & L. sseliwanoffi & L. evsyukovi \\
\hline Coxal pores & $1,2,2,1-3,3,3,3$ & $1,2,2,2-2,2,2,2$ & $2,4,4,3-4,5,5,4$ & $3,4,4,3-4,5,4,3$ \\
\hline $\begin{array}{l}\text { Number of } \\
\text { antennomeres }\end{array}$ & 20 & $19-20$ & 20 & $18-21$ \\
\hline Ocelli & 8 in 2 rows & $6-10$ in 2-3 rows & $6-12$ in 3 rows & $10-15$ in 3-4 rows \\
\hline Tibia 15 of male & $\begin{array}{l}\text { with a small cylindrical } \\
\text { wart with a crater at } \\
\text { apex, without setae }\end{array}$ & $\begin{array}{l}\text { with a small cylindrical } \\
\text { wart supporting a few } \\
\text { short setae at apex, } \\
\text { without crater }\end{array}$ & $\begin{array}{l}\text { with a small } \\
\text { cylindrical wart } \\
\text { supporting a few } \\
\text { short setae at apex, } \\
\text { without crater }\end{array}$ & $\begin{array}{l}\text { with a large, flat, } \\
\text { avoid few short supporting } \\
\text { apex, without crater }\end{array}$ \\
\hline $\begin{array}{l}\text { First article of } \\
\text { female gonopod }\end{array}$ & $\begin{array}{l}\text { without dorsolateral } \\
\text { setae }\end{array}$ & $\begin{array}{l}\text { without dorsolateral } \\
\text { setae }\end{array}$ & $\begin{array}{l}\text { always with 1 } \\
\text { dorsolateral seta }\end{array}$ & $\begin{array}{l}\text { with 2-4 dorsolateral } \\
\text { setae }\end{array}$ \\
\hline $\begin{array}{l}\text { Second article of } \\
\text { female gonopod }\end{array}$ & $\begin{array}{l}\text { with 3 dorsolateral } \\
\text { setae }\end{array}$ & with 2 dorsolateral setae & $\begin{array}{l}\text { with 3-5 dorsolateral } \\
\text { setae }\end{array}$ & $\begin{array}{l}\text { with 4-6 dorsolateral } \\
\text { setae }\end{array}$ \\
\hline Apical claw & $\begin{array}{l}\text { tridentate, with 1 } \\
\text { dorsolateral seta }\end{array}$ & $\begin{array}{l}\text { bidentate, with 1 } \\
\text { dorsolateral seta }\end{array}$ & $\begin{array}{l}\text { tridentate, with 3-4 } \\
\text { very short and thin } \\
\text { dorsolateral setae }\end{array}$ & $\begin{array}{l}\text { tridentate, with 3 very } \\
\text { short and thin } \\
\text { dorsolateral setae }\end{array}$ \\
\hline
\end{tabular}

Coxal pores (Fig. 22): 4,4,4,3 on both the left and right sides, arranged in a single regular row, circular, separated from one another by a space greater than their own diameter. Coxal pore field set in a relatively shallow groove.

Male S 15: posterolaterally narrower than anterolaterally, trapeziform, posterior margin almost straight;
75 short to long setae scattered sparsely over its surface and at lateral margins.

Male first genital sternite: posterior margin sinuate, posterior angles rounded, 68 short to medium setae scattered sparsely over its surface and at lateral margins (Fig. 23). 
Male gonopods: small, one-segmented, with one apical seta (see Fig. 23).

Female. Intermediate tergite: wider than that of male, lateral margins convergent anteriorly and posteriorly, posterior angles rounded, posterior margin sinuate (Fig. 21).

Female S 15: posterolaterally narrower than anterolaterally, trapeziform, wider than that of male, posterior margin almost straight; 55 short to long setae scattered sparsely over its surface and at lateral margins.

Female first genital sternite wider than long, 26-28 regularly scattered setae on each side; posterior margin with a short, posterior, truncate expansion between condyles of gonopods.

Female gonopods (Figs 26-30): first article fairly broad, bearing 14-15 long setae arranged in two irregular rows, 3-4 dorsolateral setae in a line, $2+2$ lanceolate spurs, close to each other, internal spur smaller and shorter than external one (Fig. 30). Second article with nine medium to long setae, arranged in two irregular rows on its ventral side, six dorsolateral setae in a line (Fig. 28). Apical claw tridentate (Fig. 29), curved; five short to medium setae situated at base of claw; three very short and thin dorsolateral setae in a line.

Variation. The other adult specimens examined differ from the holotype in the following characters. Length: body $8.5-13.0 \mathrm{~mm}$ long, $1.2-1.5 \mathrm{~mm}$ broad at $\mathrm{T} 10$; legs 14 and $15 \mathrm{ca} 3.5 \mathrm{~mm}$ and $4.0 \mathrm{~mm}$ long, respectively. Ocelli: $1+3,4,3,3,1+2,3,4,2,1+4,3,2$. Antennae: ca 3.2 $4.0 \mathrm{~mm}$ long, composed of 18-21 articles. Plectrotaxy: as in Table 5. Coxal pores: 4,5,4,3; 3,4,4,3. Female gonopods: with two dorsolateral setae on first article; four dorsolateral setae on second article.

NAME. Honours Aleksandr P. Evsyukov, the collector.

GENERAL DISTRIBUTION: North Caucasus.

CHOROTYPE: Central Caucasus, endemic?

ALTITUDINAL RANGE: 1850-2100 m.

REMARKS: The new species is included in the $L$. ferganensis group, whose males have a dorsodistal wart on tibia 15. The main differences between the species of this group are in plectrotaxy, the structure of the apical claw and the dorsolateral armature of the female gonopods [Farzalieva, 2006]. Eason [1997] synonymized the Caucasian L. turkestanicus Attems, 1904 and Eastern European L. sseliwanoffi Garbowski, 1897 with L. ferganensis (Trotzina, 1894), from Central Asia. However, Farzalieva [2006] considers Eason's opinion as erroneous. She considers all these species valid and we follow her in this paper.

Morphologically, this new species is close to the widespread L. sseliwanoffi. It is noteworthy that the collections from Mount Matsuta contained both species. Lithobius evsyukovi sp.n. differs from L. sseliwanoffi by following characters: a large wart on male tibia 15; the presence of 2-4 dorsolateral setae on the first article of the female gonopods (L. sseliwanoffi always has only one seta); the presence of DPa on leg- pairs 2-8 and of VFp on leg-pairs 1-10. The main differences between L. ferganensis, L. turkestanicus, L. sseliwanoffi and L. evsyukovi sp.n. are summarized in Table 6.

ACKNOWLEDGEMENTS. We thank A.P. Evsyukov (Rostov-on-Don, Russia), who gave me his material for treatment and executed the map. We are also deeply grateful to Arkady A. Schileyko (Moscow, Russia), Marzio Zapparoli (Viterbo, Italy) and G.Sh. Farzallieva (Perm, Russia) for their critical remarks on this paper. S.I. Golovatch (Moscow, Russia) provided much of the relevant literature and assisted in publication.

\section{References}

Attems C.G. 1907. Myriopoden aus der Krim und dem Kaukasus, von Dr. A. Stuxberg gesammelt // Arkif för Zoologi. Bd.3. No.25. S.1-16.

Bonato L., Edgecombe G.D., Lewis J.G.E., Minelli A., Pereira L.A., Shelley R.M., Zapparoli M. 2010. A common terminology for the external anatomy of centipedes (Chilopoda) // ZooKeys. Vol.69. P.17-51.

Chamberlin R.V. 1952. On the Chilopoda of Turkey // Revue de la Faculté des Sciences de l'Université d'Istanbul. Vol.17. No.3. P.183-258

Eason E.H. 1997. On some Lithobiomorpha from the mountains of Kirghizia and Kazakhstan (Chilopoda) // Arthropoda Selecta. Vol.6. Nos 1-2. P.117-121.

Farzalieva G.Sh. 2006. New species of the lithobiid genus Lithobius (Monotarsobius) (Chilopoda: Lithobiomorpha: Lithobiidae) from eastern Kazakhstan // Arthropoda Selecta. Vol.15. No.2. P.99-117.

Farzalieva G.Sh., Zalesskaja N.T. 2002. On two remarkable species of lithobiid centipedes (Chilopoda: Lithobiomorpha: Lithobiidae) from the steppe of the southern Urals, Russia // Arthropoda Selecta Vol.11. No.4. P.265-269.

Folkmanova B. 1958. [On new forms of Chilopoda from the USSR] // Zoologicheskii Zhurnal. T.37. No.2. P.183-192 [in Russian, German summary].

Lignau N.G. 1903. Die Myriopoden der Pontus-Küsten von Caucasus // Zapiski Novorossiyskago Obshchestva estestvoispytateley. T.25. P. 82-125 [in Russian and German].

Muralewicz W.S. 1907. Zur Myriapodenfauna des Kaukasus. // Zoologischer Anzeiger. Bd.31. H.11-12. S.329-351.

Muralewicz W.S. 1926. Übersicht über die Chilopodenfauna des Kaukasus. II // Zoologischer Anzeiger. Bd.69. H.1-2. S.27-44.

Muralewicz W.S. 1929. [Scutigeridae and Lithobiidae of the Caucasian fauna] // Mémoires de la Séction Zoologique de la Société des Amis des Sciences Naturelles, d'Anthropologie et d'Ethnographie. T.4. P.1-120 [in Russian].

Sseliwanoff A.V. 1881. [Myriapoden des Kaukasus] // Trudy russkogo entomologicheskogo obshchestva, Peterburg. T.12. No.6. P.177-198 [in Russian].

Zalesskaja N.T. 1973. [The lithobiids (Chilopoda, Lithobiidae) of the Caucasus, their distribution and connection to the soil] // Ghilarov M.S. (ed.). Ekologiya pochvennykh bespozvonochnykh. Moscow: Nauka. P.120-130 [in Russian].

Zalesskaja N.T. 1978. [Identification book of the lithobiomorph centipedes of the USSR (Chilopoda, Lithobiomorpha)]. Moscow: Nauka. 212 pp. [in Russian].

Zapparoli M. 1994. Chilopodi di Turchia. IV. Specie del genere Lithobius Leach, 1814 s. str. (Chilopoda, Lithobiomorpha) // Fragmenta Entomologica, Vol.25. No.2. P.175-256.

Zapparoli M. 1999. The present knowledge of the centipede fauna of Anatolia (Chilopoda) // Biogeographia, Lavori delle Società Italiana di Biogeografia, Nuova Serie. Vol.20. P.105177.

Responsible editor S.I. Golovatch 